\title{
The Factors That Affect the Expansion of the Tape for It to Avoid Side Effects in the Production of Composites in Online LATP Technology
}

\author{
Svetlana Risteska ${ }^{1, *}$, Samoil Samak ${ }^{1}$ and Vele Samak ${ }^{2}$ \\ 1 Institute for Advance and Composite and Robotics, Krusevski pat bb, 7500 Prilep, North Macedonia; \\ ssamak@mail.mikrosam.com \\ 2 Mikrosam D.O.O., Krusevski pat bb, 7500 Prilep, North Macedonia; vsamak@mail.mikrosam.com \\ * Correspondence: svetler@mail.mikrosam.com
}

check for

updates

Citation: Risteska, S.; Samak, S.; Samak, V. The Factors That Affect the Expansion of the Tape for It to Avoid Side Effects in the Production of Composites in Online LATP Technology. J. Compos. Sci. 2021, 5, 284. https://doi.org/10.3390/ jcs5100284

Academic Editor:

Francesco Tornabene

Received: 2 September 2021

Accepted: 11 October 2021

Published: 19 October 2021

Publisher's Note: MDPI stays neutral with regard to jurisdictional claims in published maps and institutional affiliations.

Copyright: (c) 2021 by the authors. Licensee MDPI, Basel, Switzerland. This article is an open access article distributed under the terms and conditions of the Creative Commons Attribution (CC BY) license (https:/ / creativecommons.org/licenses/by/ $4.0 /)$.

\begin{abstract}
During LATP (laser automated tape placement), the compaction roller contacts the prepreg and affects the pressure distribution directly. Moreover, the design parameters of the roller are optimized with the aim of improving pressure uniformity. This paper examines the impact of the contact line and surface that depends on the compaction force, the design of the roller, the angle of inclination and the angle of inclination of the strip. These factors significantly affect the expansion of the tape, and it is important to determine it to avoid side effects in the production of composites (formation of gaps or overlaps). Their presence increases the percentage of pores of the final material and thus reduces the mechanical properties. The results show that the pressure uniformity can be improved significantly by design optimization of the roller, which indicates that higher bond quality between layers is achieved. The lower the speed and higher the compact force in this technology give better intimate contact with a lower percentage of voids and good mechanical characteristics.
\end{abstract}

Keywords: thermoplastic; laser-assisted automated tape placement (LATP); compaction roller; compaction pressure

\section{Introduction}

Thermoplastic tape placement is a special case of an out of autoclave process; it has a high potential for the aerospace industry due to its high degree of automation. Unidirectional (UD) continuous fiber-reinforced tapes with high fiber content are used as semi-finished material. Within the laser thermoplastic tape placement process, tapes are melted by a heat source, such as a laser beam, and bonded to laminates by compaction force induced by a consolidation roller. However, the achieved consolidation quality, especially the interlaminar void content, does not meet the standards of the aerospace industry yet. This paper aims to investigate the effect of the compaction force on the consolidation state of the incoming tape and its consequences on the governing mechanisms during consolidation. For this purpose, experimental research has been performed to analyze the state of the tape during the LATP process. In recent years, more research has been conducted to understand the parameters that affect the heating, compaction and cooling phases of the LATP process [1-4].

The development of intimate contact between the layers, which is a prerequisite for bonding, consists of equalizing the unevenness of the tape and the laminate. Firstly, bond strength in regions where intimate contact is achieved, then interdiffusion of polymer chains occurs due to accidental thermal movement. The interdiffusion process is generally explained by the mobility of the polymer chains. The polymer matrix consists of intertwined chains that have limited movement. Their mobility, and thus the degree of diffusion, increases with increasing temperature [4-6]. Secondly, inter-laminar void content in the final structure is a direct result of intimate contact development. Interlaminar voids reduce 
the mechanical performance of the final product [7]. The heat transfer might be reduced at the ply interfaces if they have incomplete intimate contact $[4,8,9]$; therefore, since the temperature affected the crystallinity, porosity, decomposition and residual stresses, we can conclude that intimate contact has a great influence on the characteristics of the final products produced with the LATP process [10-23].

The roller used for compaction is usually coated with siliconized rubber and directly affects the LATP process. Different silicone thicknesses of the roller have a different effect on the intimate contact. This is explored by several authors [24-26]. Lichtinger et al. [24] numerically and experimentally analyzed the roller deformation behavior of the mold. Cheng et al. [26] again studied the characteristic of contact and the morphological change of the barrier under the roller. More research is being done on how to increase pressure uniformity by optimizing the roller structure. Compressive strength is an important parameter of the ATP process [27-34]. There is a direct relationship between the compressive strength, the void content and the bond strength between laminates for thermoplastic matrix composites [27-32].

This paper examines the impact of the contact line and surface that depends on the compaction force, the design of the roller, the angle of inclination and the angle of inclination of the strip. These factors significantly affect the expansion of the tape, and it is important to determine it to avoid side effects in the production of composites (formation of gaps or overlaps). Their presence increases the percentage of pores of the final material and thus reduces the mechanical properties. The purpose of this paper is to see the impact of the parameters on the bandwidth (avoiding gaps and overlaps when generating a composite program with a $25.4 \mathrm{~mm}$ wide band). The experimental results in this paper help to better understand the consolidation process during LATP.

\section{Experimental Details}

\subsection{Materials and Methods}

The thermoplastic composite materials evaluated in this study are:

- $\quad$ UD prepreg material LM-PAEK Toray TC1225 Cetex ${ }^{\circledR} /$ T700

- UD prepreg material PEKK/CF Ten Cate TC1320/AS4

All characteristics of the UD prepregs are summarized in Table 1. The tapes with $25.4 \mathrm{~mm}$ width were selected for the LATP process investigated in this work.

Table 1. Description of UD prepregs (used in this study).

\begin{tabular}{ccc}
\hline Materials & LM-PAEK Toray TC1225 Cetex ${ }^{\circledR} /$ T700 & PEKK/CF Ten Cate TC1320/AS4 \\
\hline Prepreg areal weight & $220 \mathrm{~g} / \mathrm{m}^{2}$ & $220 \mathrm{~g} / \mathrm{m}^{2}$ \\
\hline Fiber areal weight & $145 \mathrm{~g} / \mathrm{m}^{2}$ & $145 \mathrm{~g} / \mathrm{m}^{2}$ \\
\hline Matrix content & $34 \mathrm{wt} \%$ & $34 \mathrm{wt} . \%$ \\
\hline Nominal thickness & $0.14 \mathrm{~mm}$ & $0.14 \mathrm{~mm}$ \\
\hline Matrix glass transition temperature $(\mathrm{Tg})$ & $147^{\circ} \mathrm{C}$ & $160{ }^{\circ} \mathrm{C}$ \\
\hline Matrix melting temperature $(\mathrm{Tm})$ & $305^{\circ} \mathrm{C}$ & $337^{\circ} \mathrm{C}$ \\
\hline
\end{tabular}

\subsection{LATP Process (Laser-Assisted ATP Manufacturing)}

The samples for the experimental tests were made at IACR of a six-axis robotic machine manufactured by Mikrosam. The parts of the machine are shown in Figure 1:

1. Consolidation roller with outer diameter of $60 \mathrm{~mm}$

2. Spool for UD tape

3. Laser Heat source $3 \mathrm{~kW}$ Laser line LDF series diode laser system (optic lens $33 \times 43 \mathrm{~mm}$ and focal distance $200 \mathrm{~mm}$ ).

4. Mandrel/Tool 


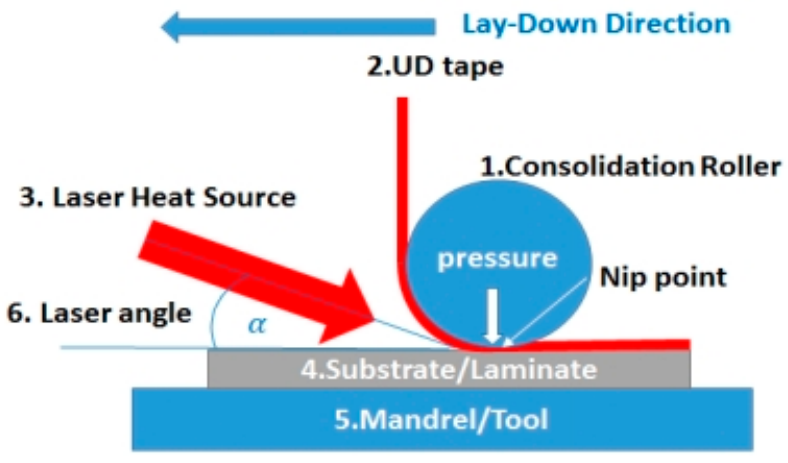

Figure 1. A laser-assisted tape placement head (LATP).

The material used in this study was TC1320-1 CF/PEKK supplied by Ten Cate and LM-PAEK TC1225 Cetex ${ }^{\circledR} /$ T700 in 1 in. slit tapes. The laying of the samples takes place on a flat aluminum table with several variable process parameters, as given in Table 1. The minimum and maximum values of compact pressure, lay-up speed, inclination angle and laying angle were taken as variable parameters. The experiments were performed with different combinations of the previously listed variable process parameters in LATP technology. In order for the amorphous phase of the polymer PEEK to remain in the glass state and not cause further changes in the microstructure after compaction, the mass at which the sample is placed is heated to $175^{\circ} \mathrm{C}$ to allow the compacted strip to cool below its glass transition temperature $\left(160^{\circ} \mathrm{C}\right)$. Samples for mechanical tests were cut from the mid-section of the flat pallets so that the acceleration and deceleration phases of the placement head did not affect the microstructure.

A thermal camera was used to monitor the surface temperature of the strip during the laying process.

\subsection{Pressure Measurement}

The actual pressure distribution under the compaction roller is unknown in the LATP process, so during placement, the compaction roller applies the pressure while rotating. However, the effect of roller rotation on the normal pressure is negligible, and the dynamic case can be simplified into a static one [7]. To measure the contact area under the roller so that the pressure can be calculated, knowing the predetermined force, pressure-sensitive films are used, as demonstrated in Figure 2. During the experiments, a force of 200 to $1000 \mathrm{~N}$ was used, with a step of $200 \mathrm{~N}$. Then, the dimensions of the stains on the pressurized films were measured, and the contact surface was calculated. The contact surface was calculated for each force in order to determine the pressure.

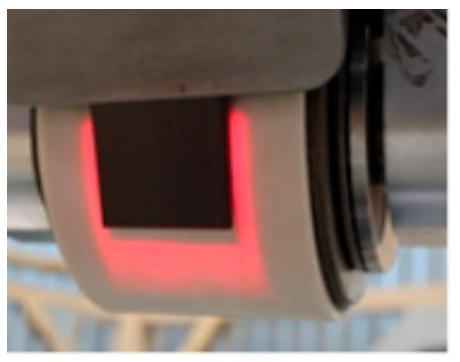

(a)

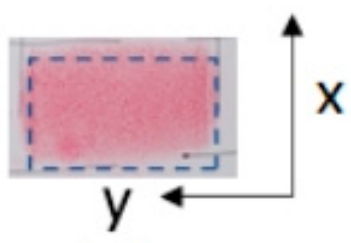

(b)

Figure 2. (a) Static pressure application with the LATP machine; (b) a stained pressure film with the assumed uniform pressure area.

The main factors that affect the intimate contact of this process are the compact force, the temperature of the laser, the speed of laying, the tilt angle of the head, angle of the laser, 
the thickness of the roller, the roughness of the surface of the tape, etc. For this purpose, the following parameters were taken as variables:

- Compact force (400-600 N)

- $\quad$ Thickness of the siliconized layer of the roller (P1 thickness of silicon $5 \mathrm{~mm}$ and P2 thickness of silicon $15 \mathrm{~mm}$ )

- $\quad$ Tilt angle of the head (10-13 deg)

- $\quad$ Angle of lay up $(0,45,-45,90 \mathrm{deg})$

Other parameters were taken as constants. The contact line La formed during compaction of the base or contact surface depends on the compaction force, the type of roller (design of the thickness of the siliconized layer), the angle of inclination of the machine head, the diameter of the roller and the angle at it which takes the tape. In order to measure the contact area, paper is used, and the dimensions are measured. The obtained values that are measured are given in a table, graphs and diagrams are obtained from the obtained incision.

Figure 3 shows the results of the analysis of the change in the shape of the rollers as a function of compaction force; the measurements are shown, including a linear fit for each of the four variables. Roller 1 (P1) is stiffer than roller 2 (P2), and this can be observed in the relation between the compaction force and the shape of the roller. Figure $3 \mathrm{~b}$ shows that La increases with increasing compaction force. This effect is more apparent for roller 2 with a $15 \mathrm{~mm}$ thickness.

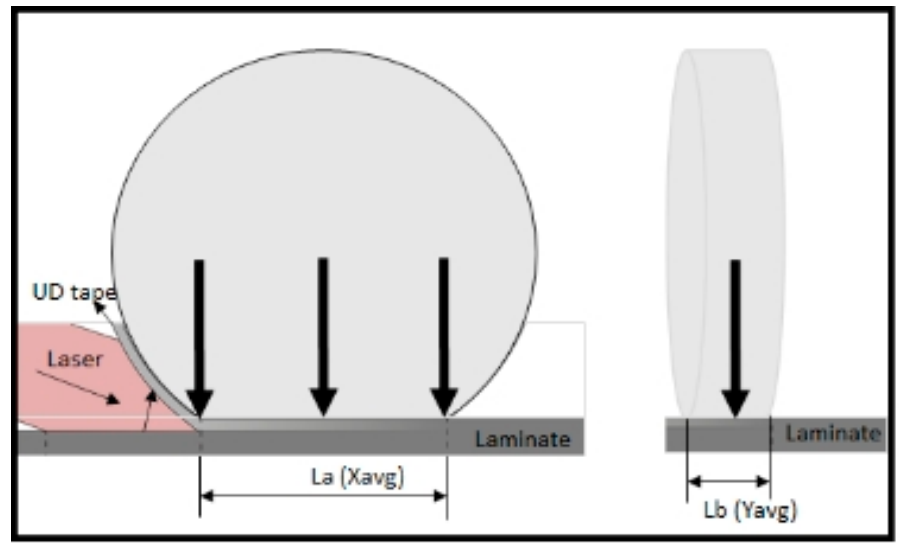

(a)

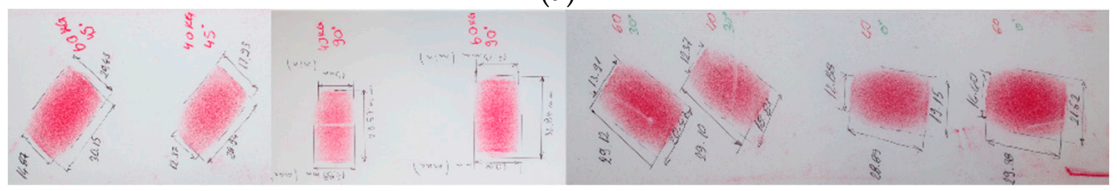

(b)

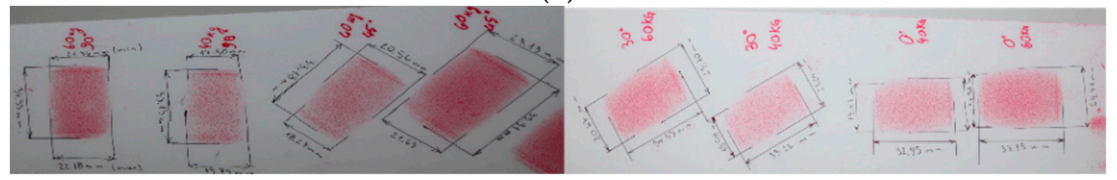

(c)

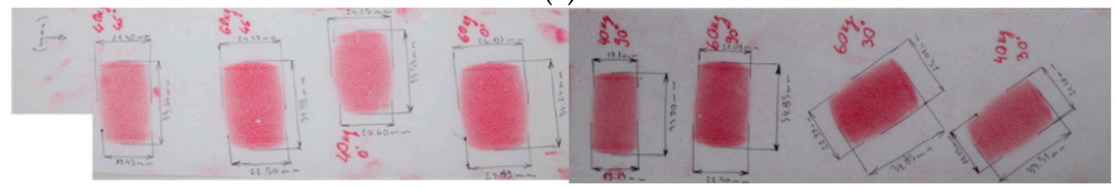

(d)

Figure 3. Compaction pressure distribution measurement experiment—color density distribution on the pressure measurement film after the pressure; (a) contact between rollers and flat molds (b) around $\mathrm{P} 1$ and tilt angle $10^{\circ} ;$ (c) around $\mathrm{P} 2$ and tilt angle $10^{\circ} ;(\mathbf{d})$ around point $\mathrm{P} 2$ and tilt angle $13^{\circ}$. 


\subsection{ILSS and Void}

In order to see how the compact force acts on the mechanical characteristics while paying attention to the width of the strip depending on the angle of laying (which was measured in the previous part) in order to avoid gaps and overlap, composite plates were produced with two compaction forces (200 and 1000) and two different passing speeds ( 3 and $6 \mathrm{~m} / \mathrm{min}$ ) for both materials. The other variables are constant (angle of the head, 13 degrees; design $(0, \pm 45,90)$, number of layers, 16 ; laser temperature (for PEKK $420{ }^{\circ} \mathrm{C}$, for PAEK $350^{\circ} \mathrm{C}$ ); mass temperature, $175^{\circ} \mathrm{C}$ ). Production of the produced plates is given with a picture, Figure 4 . From the obtained plates using the two standards ASTM D2734 and ASTM D2344, pores and ILSS are calculated for both materials. The value of contact line (La) for different rollers, lead angle and angle of lay-up are given in Table 2.

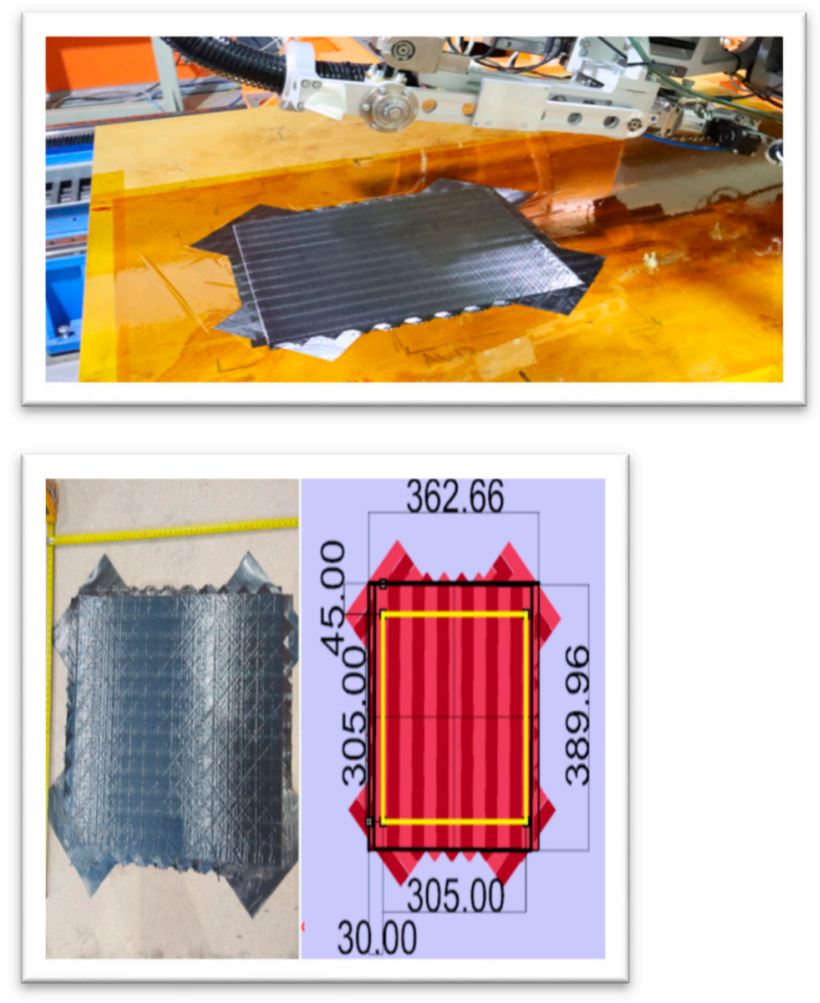

Figure 4. Production of composite flat pallets with LATP technology.

Table 2. The value of contact line (La) for different rollers, lead angle and angle of lay-up.

\begin{tabular}{|c|c|c|c|c|c|c|c|c|c|c|c|}
\hline & \multirow[b]{2}{*}{$\begin{array}{l}\text { Angle } \\
\text { of lay } \\
\text { up }\end{array}$} & \multirow[b]{2}{*}{$\begin{array}{l}\text { Compaction } \\
\text { force } \\
\text { (N) }\end{array}$} & \multicolumn{3}{|c|}{$\begin{array}{l}\text { Roller 1(P1) } \\
\text { Diameter ø60, Wide } 35 \mathrm{~mm} \text {, } \\
\text { Thickness of Silicon } 5 \mathrm{~mm}\end{array}$} & \multicolumn{3}{|c|}{$\begin{array}{l}\text { Roller 2(P2) } \\
\text { Diameter ø60, Wide } 35 \mathrm{~mm} \text {, } \\
\text { Thickness of Silicon } 15 \mathrm{~mm}\end{array}$} & \multicolumn{3}{|c|}{$\begin{array}{l}\text { Roller 2(P2) } \\
\text { Diameter ø60, Wide } 35 \mathrm{~mm} \text {, } \\
\text { Thickness of Silicon } 15 \mathrm{~mm}\end{array}$} \\
\hline & & & \multicolumn{2}{|c|}{$\begin{array}{l}\text { Contact line La } \\
(\mathrm{mm})\end{array}$} & \multirow{2}{*}{$\begin{array}{c}\text { Pressure } \\
\mathrm{N} / \mathrm{mm}^{2}\end{array}$} & \multicolumn{2}{|c|}{$\begin{array}{l}\text { Contact line La } \\
(\mathrm{mm}) \\
\left(\text { Lead angle } 10^{\circ}\right)\end{array}$} & \multirow{2}{*}{$\begin{array}{c}\text { Pressure } \\
\mathrm{N} / \mathrm{mm}^{2}\end{array}$} & \multicolumn{2}{|c|}{$\begin{array}{l}\text { Contact line La } \\
\quad(\mathrm{mm}) \\
\left(\text { Lead angle } 13^{\circ}\right)\end{array}$} & \multirow{2}{*}{$\begin{array}{c}\begin{array}{c}\text { Pressure } \\
\text { N/mm }\end{array} \\
0.49\end{array}$} \\
\hline 1 & 0 & 400 & 19.15 & 553 & & 19.987 & 641.54 & & 22.425 & 813.1 & \\
\hline 3 & \pm 30 & 400 & 19.06 & 554.97 & 0.72 & 19.81 & 698.95 & 0.57 & 20.445 & 707.06 & 0.57 \\
\hline 5 & \pm 45 & 400 & 18.34 & 529.565 & 0.76 & 18.62 & 682.18 & 0.59 & 20.375 & 716.53 & 0.56 \\
\hline 7 & 90 & 400 & 17.89 & 528.71 & 0.76 & 19.415 & 653.99 & 0.61 & 18.615 & 652.34 & 0.61 \\
\hline 2 & 0 & 600 & 21.52 & 632 & 0.95 & 22.996 & 823.84 & 0.73 & 24.98 & 892.64 & 0.67 \\
\hline 4 & \pm 30 & 600 & 20.85 & 619 & 0.97 & 22.185 & 818.36 & 0.73 & 23.995 & 871.6 & 0.69 \\
\hline 6 & \pm 45 & 600 & 20.33 & 609 & 0.99 & 22.38 & 784.34 & 0.76 & 23.615 & 851.06 & 0.71 \\
\hline 8 & 90 & 600 & 20.01 & 657 & 0.91 & 21.77 & 765.87 & 0.78 & 21.795 & 784.12 & 0.77 \\
\hline
\end{tabular}


The void content can be obtained by measuring the density of the fibers and the resin separately. Together with their weight fractions of the composite, this would yield a theoretical density, which can be compared to the actual density of the composite. The density should theoretically only contain the fibers and the resin with no void inclusions. In actuality, voids are presumably present. Since voids add volume but not mass, the presence of voids will decrease density. Therefore, the difference between the theoretical and measured density of the composite is the void content in volume fraction. Described in ASTM D2734, the void content can then be computed with the following equation:

$$
\mathrm{V}=100(\mathrm{Td}-\mathrm{Md}) / \mathrm{Td}
$$

where:

$$
\begin{gathered}
\qquad \mathrm{V}=\text { void content, volume } \%, \\
\mathrm{Td}=\text { theoretical composite density, as follows: } \mathrm{Td}=100 /(\mathrm{R} / \mathrm{D}+\mathrm{r} / \mathrm{d})
\end{gathered}
$$

where: $\mathrm{Td}=$ theoretical density, $\mathrm{R}=$ resin in composite, weight $\%, \mathrm{D}=$ density of resin, $\mathrm{r}=$ reinforcement in composite, weight $\%$, and $\mathrm{d}=$ density of reinforcement. Md = measured composite density using Test Methods ASTM D 792. The volume of each specimen for this test shall not be less than $2 \mathrm{~cm}^{3}$.

The ILSS ASTM D2344 test method determines the short-beam strength of highmodulus fiber-reinforced composite materials. The specimen is a short beam with a thick laminate from $2 \mathrm{~mm}$ up to $6 \mathrm{~mm}$ according to standard dimensions with a length of the span (L) - is thickness $\times 4 \mathrm{~mm}$. The specimen is loaded in three-point bending with a speed of testing of $1 \mathrm{~mm} / \mathrm{min}$.

\section{Results and Discussion}

\subsection{The Factors Affect the Expansion of the Tape}

During LATP, uncontrolled compaction pressure can cause defects (interstitial cavity, cavity, overlap. Therefore, this must be studied. With the help of the compaction roller, a compact surface is obtained under the roller. The compact force and the surface coming from the roller determines the pressure.

In this article, this surface that occurs under the roller is determined by an experiment with pressure-sensitive films. The results show that defining the width of the tape after the compaction force (that differ from differing factors, Figure 3) will make the correct generation of the flat pallet in order to avoid defects (gaps and overlap) during the LATP process.

The contact length, La, increases with increasing compaction force, and the rate is the same for both rollers. This means that pressure is applied for a longer duration during the process and more time is available for consolidation. The average pressure applied does not, however, increase at the same rate as the compaction force due to the increase in the contact length. The pressure can be increased with roller 1, and the contact length is shorter than for roller 2 at the same compaction force. Furthermore, it should be noted that the position of the nip-point is not constant and moves with a change in contact length. As the compaction force increases, the compaction roller deforms more and more, so that the area under the rollers increases, which is a limitation for achieving high pressure. The average compaction pressure has a non-linear relationship with the applied compaction force, as shown in Figure 5. The results in Figure 5 provide useful information for further discussion. 


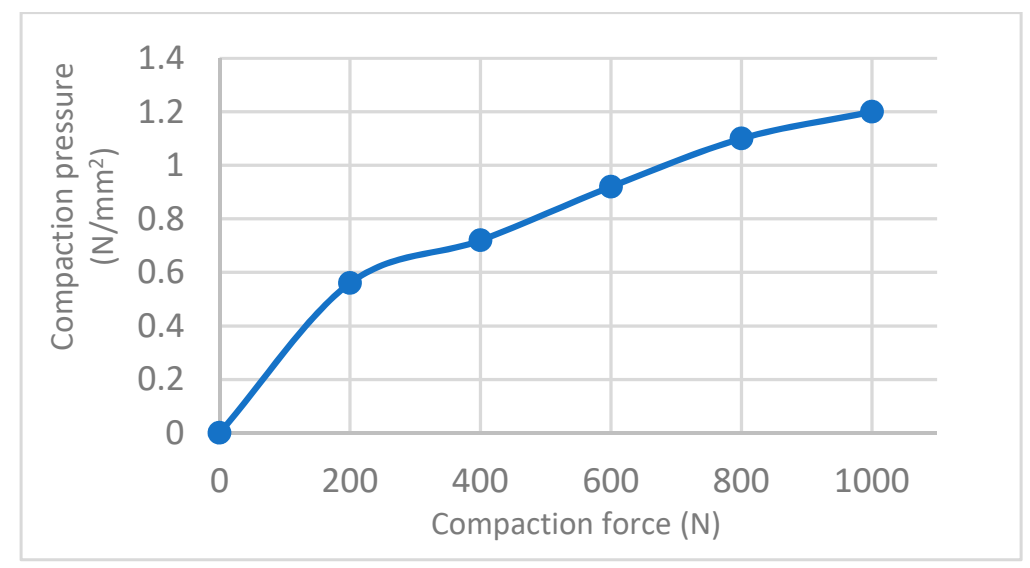

Figure 5. Compaction force vs. compaction pressure.

From Figure $6 \mathrm{a}$, it can be concluded that by increasing the angle of lay up from 0 to $90 \mathrm{deg}$, the contact line decreases, and by increasing the compact force, the contact line (La) increases. From Figure $6 b$, it can be concluded that the roller with a smaller silicon thickness has a smaller contact line (La).
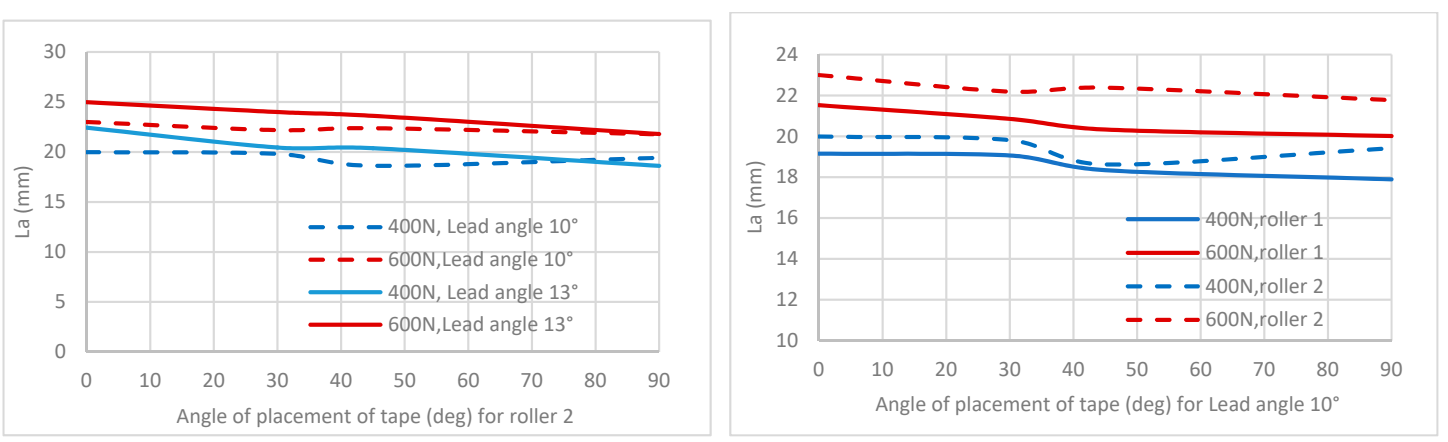

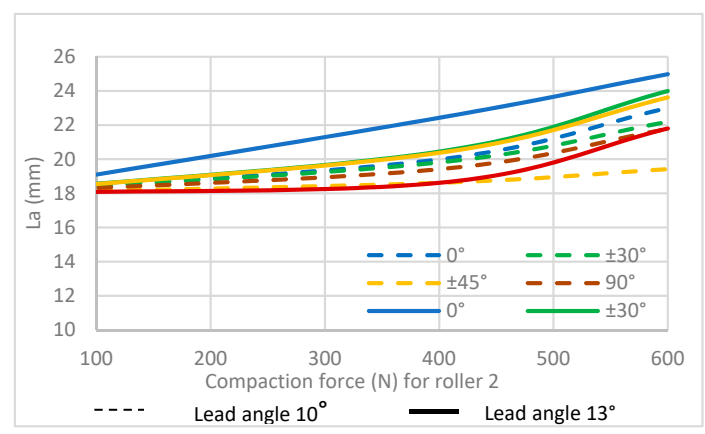

(a)

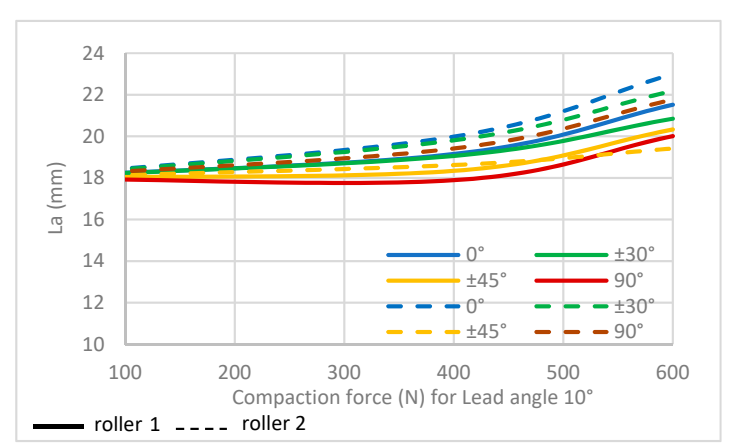

(b)

Figure 6. Influence of compact force on the contact line, La, from different angles of laying up; (a) for two different lead angles $\left(10^{\circ}\right.$ and $\left.13^{\circ}\right)$; (b) for two rollers of different thicknesses (5 and $15 \mathrm{~mm}$ ).

The influence of compact pressure factors is also shown in Figure 7. From the results (Figures 6 and 7) obtained in the analysis of the impact of the contact force, the angle of inclination, the angle of the head and the design of the thickness of the compaction roller on the contact line (contact area), it was noticed that it must be controlled and determined for different materials before the LATP process. This is important to determine the exact spread of the strip that is laid after the compaction in order to have the correct gaps between courses. If this is not specified, gaps and overlaps will occur, which will affect the mechanical properties of the final material. 


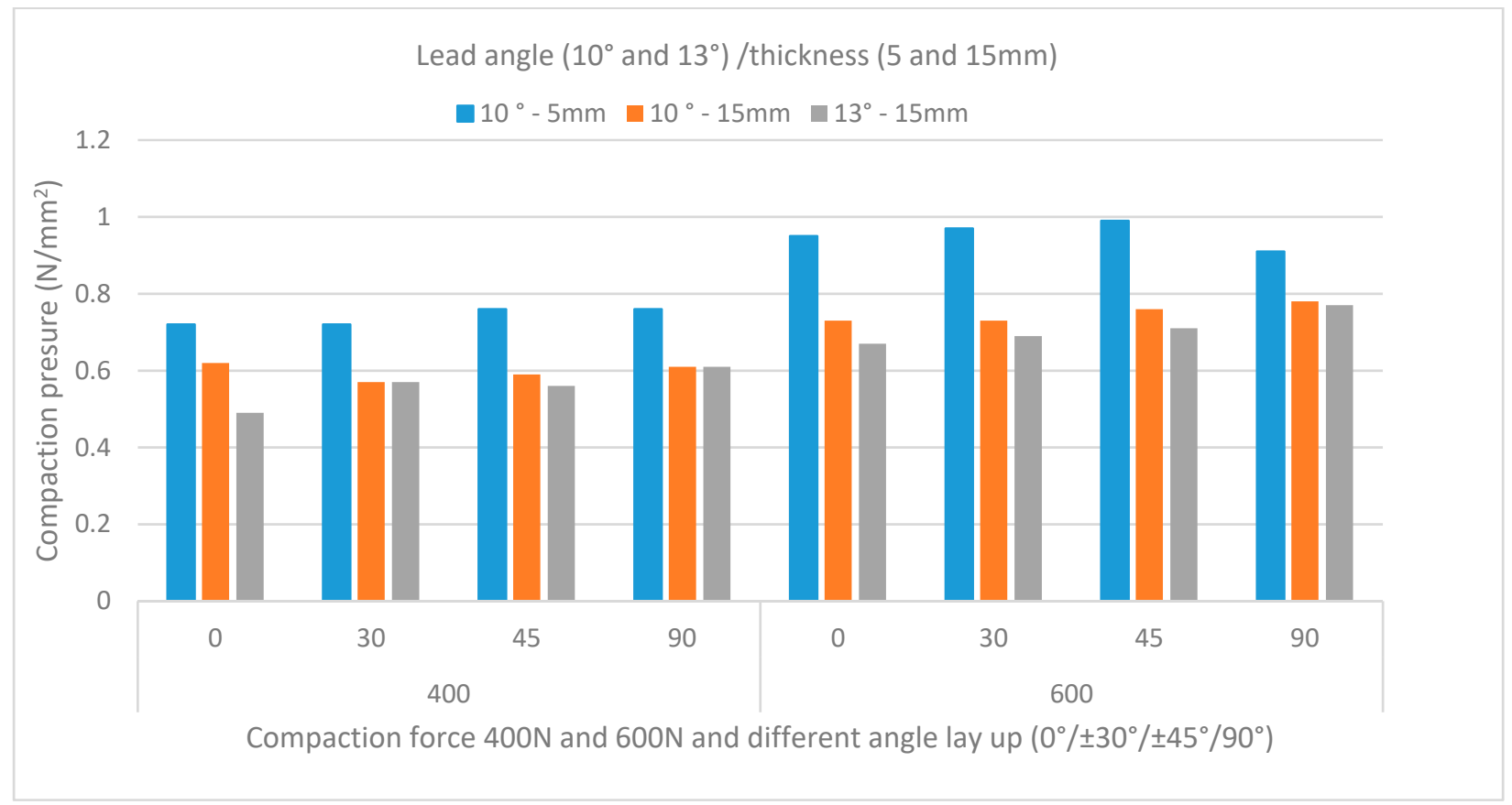

Figure 7. Compaction pressure for different factors.

\subsection{ILSS and Void}

In order to see how the compact force affects different speeds and different materials, and previously to use the data obtained for the analysis of bandwidth, eight plates with different parameters were produced.

Using the previously mentioned formulas from the standards (ASTM D2734 and ASTM D2344) for the calculation of pores and ILSS, after five repetitions for each part and with an average value and standard deviation less than 10, the calculations are made (these results are shown in Table 3). From the obtained values, diagrams are obtained for the porosity and for the ILSS calculated according to the standard for both materials, shown in Figure 8.

Table 3. ILSS and voids for different compaction forces, speeds and materials.

\begin{tabular}{|c|c|c|c|c|c|c|c|c|c|}
\hline \multicolumn{5}{|c|}{ Parameters } & \multicolumn{5}{|c|}{ Void Calculations via Theoretical Density } \\
\hline \multirow{2}{*}{$\frac{0}{0}$} & \multirow{2}{*}{$\begin{array}{c}\mathrm{N} \\
\begin{array}{c}\text { Compaction } \\
\text { Force }\end{array} \\
\end{array}$} & \multirow{2}{*}{$\begin{array}{c}\text { (m/min) } \\
\text { Lay up } \\
\text { Speed }\end{array}$} & \multirow{2}{*}{$\begin{array}{c}\text { No. } \\
\text { Samp. }\end{array}$} & \multirow{2}{*}{$\frac{(\mathrm{g} / \mathrm{cm} 3)}{\mathrm{Md}}$} & \multirow{2}{*}{$\begin{array}{c}\text { g/cm3) } \\
\text { Td } \\
\text { Averge }\end{array}$} & \multirow{2}{*}{$\begin{array}{c}\%) \\
\text { Voids }\end{array}$} & \multicolumn{3}{|c|}{ Voids Average (\%) } \\
\hline & & & & & & & Vav (\%) & Sn-1 & $\mathrm{CV}$ \\
\hline \multirow{5}{*}{ 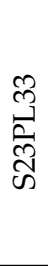 } & 200 & 3 & 1 & 1.542 & 1.59 & 3.019 & 3.55 & 0.39 & 10.97 \\
\hline & 200 & 3 & 2 & 1.525 & 1.59 & 4.088 & & & \\
\hline & 200 & 3 & 3 & 1.533 & 1.59 & 3.585 & & & \\
\hline & 200 & 3 & 4 & 1.532 & 1.59 & 3.648 & & & \\
\hline & 200 & 3 & 5 & 1.536 & 1.59 & 3.396 & & & \\
\hline \multirow{5}{*}{ 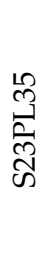 } & 1000 & 3 & 1 & 1.56 & 1.59 & 1.887 & 1.75 & 0.14 & 8.18 \\
\hline & 1000 & 3 & 2 & 1.616 & 1.59 & 1.900 & & & \\
\hline & 1000 & 3 & 3 & 1.569 & 1.59 & 1.671 & & & \\
\hline & 1000 & 3 & 4 & 1.563 & 1.59 & 1.698 & & & \\
\hline & 1000 & 3 & 5 & 1.565 & 1.59 & 1.572 & & & \\
\hline
\end{tabular}


Table 3. Cont.

\begin{tabular}{|c|c|c|c|c|c|c|c|c|c|c|}
\hline \multirow{5}{*}{ 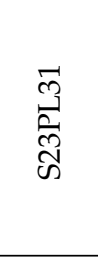 } & 200 & 6 & 1 & 1.537 & 1.59 & 3.333 & 3.38 & \multicolumn{2}{|c|}{0.20} & 5.94 \\
\hline & 200 & 6 & 2 & 1.532 & 1.59 & 3.648 & & & & \\
\hline & 200 & 6 & 3 & 1.538 & 1.59 & 3.270 & & & & \\
\hline & 200 & 6 & 4 & 1.54 & 1.59 & 3.145 & & & & \\
\hline & 200 & 6 & 5 & 1.534 & 1.59 & 3.522 & & & & \\
\hline \multirow{5}{*}{$\begin{array}{l}\text { N } \\
\text { त्र } \\
\text { N }\end{array}$} & 1000 & 6 & 1 & 1.55 & 1.59 & 2.216 & 2.28 & \multicolumn{2}{|c|}{0.10} & 4.38 \\
\hline & 1000 & 6 & 2 & 1.532 & 1.59 & 2.248 & & & & \\
\hline & 1000 & 6 & 3 & 1.551 & 1.59 & 2.208 & & & & \\
\hline & 1000 & 6 & 4 & 1.508 & 1.59 & 2.452 & & & & \\
\hline & 1000 & 6 & 5 & 1.54 & 1.59 & 2.285 & & & & \\
\hline \multirow{5}{*}{ 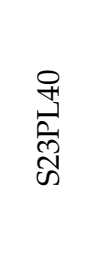 } & 200 & 3 & 1 & 1.512 & 1.59 & 4.906 & 4.31 & \multicolumn{2}{|c|}{0.40} & 9.16 \\
\hline & 200 & 3 & 2 & 1.508 & 1.59 & 4.507 & & & & \\
\hline & 200 & 3 & 3 & 1.53 & 1.59 & 3.974 & & & & \\
\hline & 200 & 3 & 4 & 1.537 & 1.59 & 3.983 & & & & \\
\hline & 200 & 3 & 5 & 1.52 & 1.59 & 4.203 & & & & \\
\hline \multirow{5}{*}{$\begin{array}{l}\text { F } \\
\text { 尝 } \\
\text { के }\end{array}$} & 1000 & 3 & 1 & 1.572 & 1.59 & 1.532 & 1.76 & \multicolumn{2}{|c|}{0.20} & 11.45 \\
\hline & 1000 & 3 & 2 & 1.532 & 1.59 & 1.780 & & & & \\
\hline & 1000 & 3 & 3 & 1.579 & 1.59 & 1.692 & & & & \\
\hline & 1000 & 3 & 4 & 1.541 & 1.59 & 2.082 & & & & \\
\hline & 1000 & 3 & 5 & 1.586 & 1.59 & 1.716 & & & & \\
\hline \multirow{5}{*}{ 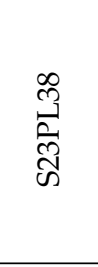 } & 200 & 6 & 1 & 1.523 & 1.59 & 4.214 & 4.86 & \multicolumn{2}{|c|}{0.47} & 9.57 \\
\hline & 200 & 6 & 2 & 1.503 & 1.59 & 5.472 & & & & \\
\hline & 200 & 6 & 3 & 1.503 & 1.59 & 4.707 & & & & \\
\hline & 200 & 6 & 4 & 1.506 & 1.59 & 5.083 & & & & \\
\hline & 200 & 6 & 5 & 1.529 & 1.59 & 4.836 & & & & \\
\hline \multirow{5}{*}{ 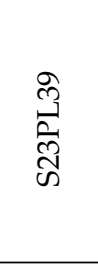 } & 1000 & 6 & 1 & 1.502 & 1.59 & 3.535 & 3.75 & \multicolumn{2}{|c|}{0.35} & 9.28 \\
\hline & 1000 & 6 & 2 & 1.521 & 1.59 & 4.340 & & & & \\
\hline & 1000 & 6 & 3 & 1.534 & 1.59 & 3.722 & & & & \\
\hline & 1000 & 6 & 4 & 1.546 & 1.59 & 3.707 & & & & \\
\hline & 1000 & 6 & 5 & 1.551 & 1.59 & 3.453 & & & & \\
\hline \multicolumn{4}{|c|}{ Parameters } & \multicolumn{7}{|c|}{ Mechanical Properties-ILSS } \\
\hline Code & $\begin{array}{c}\text { Compaction } \\
\text { Force }\end{array}$ & $\begin{array}{l}\text { Lay up } \\
\text { Speed }\end{array}$ & Sam. & Width & Thickness & $\begin{array}{l}\text { Loading } \\
\text { Force }\end{array}$ & $\tau$ & $\tau$ av & Sn-1 & CV \\
\hline & $\mathbf{N}$ & $(\mathrm{m} / \mathrm{min})$ & No. & $(\mathrm{mm})$ & $(\mathrm{mm})$ & (N) & (MPa) & (MPa) & & \\
\hline & 200 & 3 & 1 & 13.38 & 2.17 & 2377 & 61.40 & 61.42 & 5.71 & 9.30 \\
\hline$\stackrel{m}{M}$ & 200 & 3 & 2 & 13.42 & 2.26 & 2505 & 61.95 & & & \\
\hline$\vec{m}$ & 200 & 3 & 3 & 13.26 & 2.30 & 2160 & 53.12 & & & \\
\hline ऊ & 200 & 3 & 4 & 13.27 & 2.13 & 2314 & 61.40 & & & \\
\hline & 200 & 3 & 5 & 13.13 & 2.13 & 2582 & 69.24 & & & \\
\hline
\end{tabular}


Table 3. Cont.

\begin{tabular}{|c|c|c|c|c|c|c|c|c|c|c|}
\hline \multirow{5}{*}{ 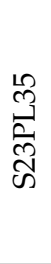 } & 1000 & 3 & 1 & 13.44 & 2.00 & 2338 & 65.23 & 64.47 & 5.48 & 8.50 \\
\hline & 1000 & 3 & 2 & 13.03 & 1.87 & 2360 & 72.64 & & & \\
\hline & 1000 & 3 & 3 & 12.98 & 1.99 & 2006 & 58.25 & & & \\
\hline & 1000 & 3 & 4 & 13.03 & 2.01 & 2125 & 60.85 & & & \\
\hline & 1000 & 3 & 5 & 12.95 & 2.06 & 2325 & 65.37 & & & \\
\hline \multirow{5}{*}{$\begin{array}{l}\vec{m} \\
\overrightarrow{\tilde{c}} \\
\text { के }\end{array}$} & 200 & 6 & 1 & 13.14 & 2.31 & 2214 & 54.71 & 55.42 & 5.36 & 9.67 \\
\hline & 200 & 6 & 2 & 13.40 & 2.25 & 2302 & 57.26 & & & \\
\hline & 200 & 6 & 3 & 13.23 & 2.13 & 1836 & 48.86 & & & \\
\hline & 200 & 6 & 4 & 13.01 & 2.26 & 2076 & 52.95 & & & \\
\hline & 200 & 6 & 5 & 13.40 & 2.17 & 2454 & 63.30 & & & \\
\hline \multirow{5}{*}{ 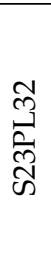 } & 1000 & 6 & 1 & 13.16 & 2.08 & 2028 & 55.57 & 56.81 & 5.25 & 9.24 \\
\hline & 1000 & 6 & 2 & 12.83 & 2.11 & 2150 & 59.56 & & & \\
\hline & 1000 & 6 & 3 & 12.54 & 2.12 & 1850 & 52.19 & & & \\
\hline & 1000 & 6 & 4 & 13.22 & 2.10 & 2387 & 64.49 & & & \\
\hline & 1000 & 6 & 5 & 12.58 & 2.23 & 1954 & 52.24 & & & \\
\hline \multirow{5}{*}{ 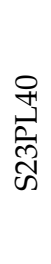 } & 200 & 3 & 1 & 12.96 & 2.24 & 1988 & 51.36 & 49.22 & 1.76 & 3.58 \\
\hline & 200 & 3 & 2 & 12.28 & 2.19 & 1823 & 50.84 & & & \\
\hline & 200 & 3 & 3 & 13.20 & 2.24 & 1909 & 48.42 & & & \\
\hline & 200 & 3 & 4 & 13.51 & 2.21 & 1887 & 47.4 & & & \\
\hline & 200 & 3 & 5 & 13.3 & 2.23 & 1902 & 48.1 & & & \\
\hline \multirow{5}{*}{$\begin{array}{l}\text { F } \\
\text { స్ } \\
\text { సै }\end{array}$} & 1000 & 3 & 1 & 13.32 & 2.34 & 2077 & 49.98 & 51.31 & 1.62 & 3.16 \\
\hline & 1000 & 3 & 2 & 12.83 & 2.31 & 2063 & 52.21 & & & \\
\hline & 1000 & 3 & 3 & 13.17 & 2.23 & 2091 & 53.40 & & & \\
\hline & 1000 & 3 & 4 & 13.13 & 2.22 & 2003 & 51.54 & & & \\
\hline & 1000 & 3 & 5 & 13.31 & 2.20 & 1930 & 49.43 & & & \\
\hline \multirow{5}{*}{ 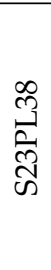 } & 200 & 6 & 1 & 13.21 & 2.20 & 1765 & 45.55 & 44.52 & 3.19 & 7.16 \\
\hline & 200 & 6 & 2 & 13.27 & 2.15 & 1813 & 47.66 & & & \\
\hline & 200 & 6 & 3 & 13.31 & 2.19 & 1760 & 45.28 & & & \\
\hline & 200 & 6 & 4 & 13.36 & 2.08 & 1666 & 44.96 & & & \\
\hline & 200 & 6 & 5 & 13.25 & 2.01 & 1390 & 39.14 & & & \\
\hline \multirow{5}{*}{$\begin{array}{l}\text { ले } \\
\text { ले } \\
\text { Wै }\end{array}$} & 1000 & 6 & 1 & 12.37 & 2.04 & 1859 & 55.25 & 54.75 & 4.85 & 8.85 \\
\hline & 1000 & 6 & 2 & 12.92 & 2.10 & 1689 & 46.69 & & & \\
\hline & 1000 & 6 & 3 & 12.25 & 2.08 & 1946 & 57.28 & & & \\
\hline & 1000 & 6 & 4 & 12.85 & 2.16 & 2038 & 55.07 & & & \\
\hline & 1000 & 6 & 5 & 12.81 & 2.10 & 2133 & 59.47 & & & \\
\hline
\end{tabular}




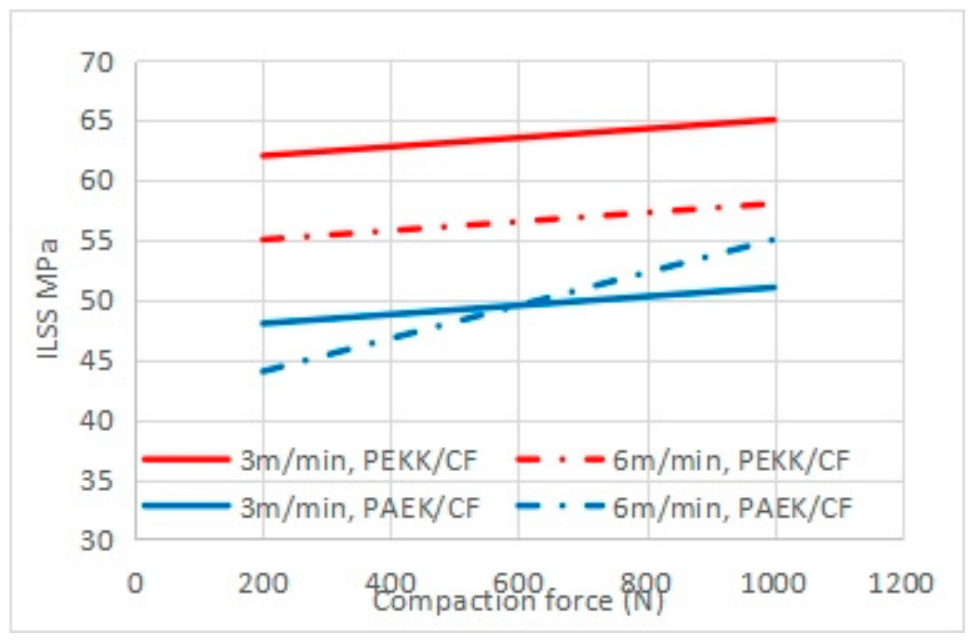

(a)

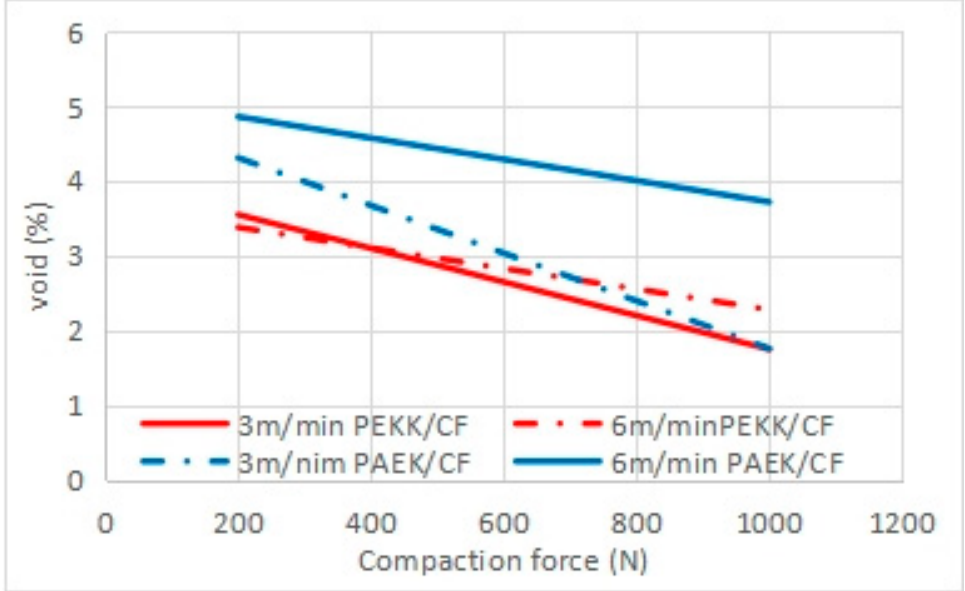

(b)

Figure 8. Influence of compact force on (a) mechanical properties of ILSS and (b) voids of different matrices and speeds.

From the obtained diagrams, it can be concluded that at lower speeds for both materials with increasing compact force, the percentage of pores decreases. From Figure 8, it is also noticed that the selected parameters give a lower percentage of pores in the boards with PEKK matrix and with lower speed. The reason for the higher percentage of pores in samples with less compact force is due to the presence of larger pores between the layers, as seen in the pictures below. The sample SL23PL35 (Figure 9), obtained by applying higher compaction force and lower speed, showed only certain areas with a polymer matrix. This means that at lower deceleration speeds and by applying higher compaction force, a good quality bonding of the layers is also achieved. The lower speed allows more time for the polymer to heat up at the coupling point, in which case, even with the application of lower pressure, good bonding and squeezing of the empty air can occur. When a higher speed is applied, as in the sample SL23PL32, and higher pressure, voids appear but not in a large percentage. This means that the higher speed does not allow enough time for good compaction when laying the layer with the previous layers, i.e., with the laminate. 


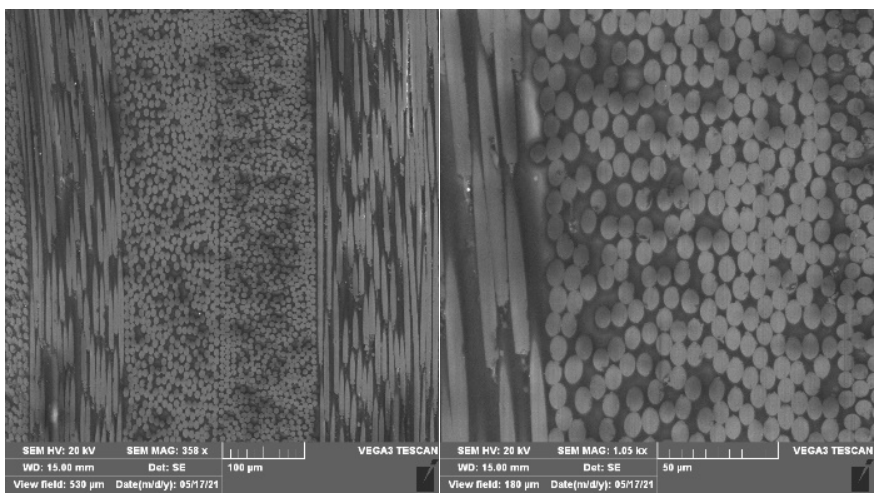

Laminate SL23PL35 PEKK/CF (1.75\% voids)

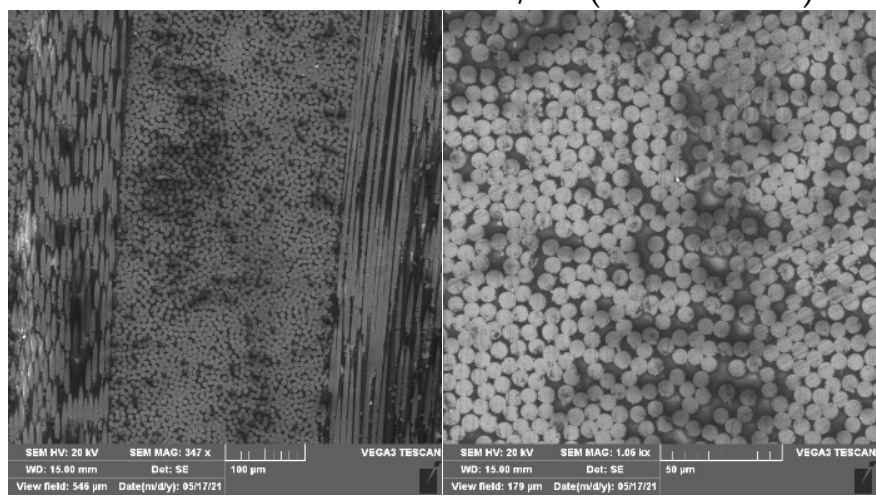

Laminate SL23PL33 PEKK/CF (3.55\% voids)

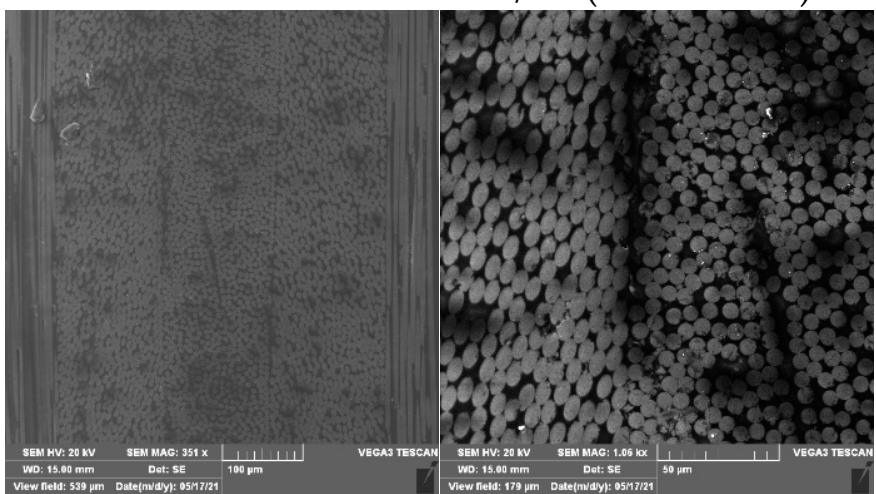

Laminate SL23PL31 PEKK/CF (3.38\% voids)

Figure 9. SEM images of the samples with PEKK resin.

The samples marked SL23PL40 and SL23PL41 are obtained with a low speed of $3 \mathrm{~m} / \mathrm{min}$ and with different compaction forces 200 and $1000 \mathrm{~N}$. The sample SL23PL40, obtained with a lower compaction force, has a higher percentage of pores, and the pores are observed in the connection of the first layers. The SEM images with larger magnification clearly show that the fibers are well coated with a matrix and that it has achieved good adhesion. In the sample SL23PL41 (Figure 10), obtained with higher compaction force, parts with extruded polymer matrix were noticed, and the pore content was $1.76 \%$. Both samples have a good interface, and a good quality connection between the layers is achieved.

The results showed that the samples with a lower percentage of voids have higher mechanical characteristics ILSS. 


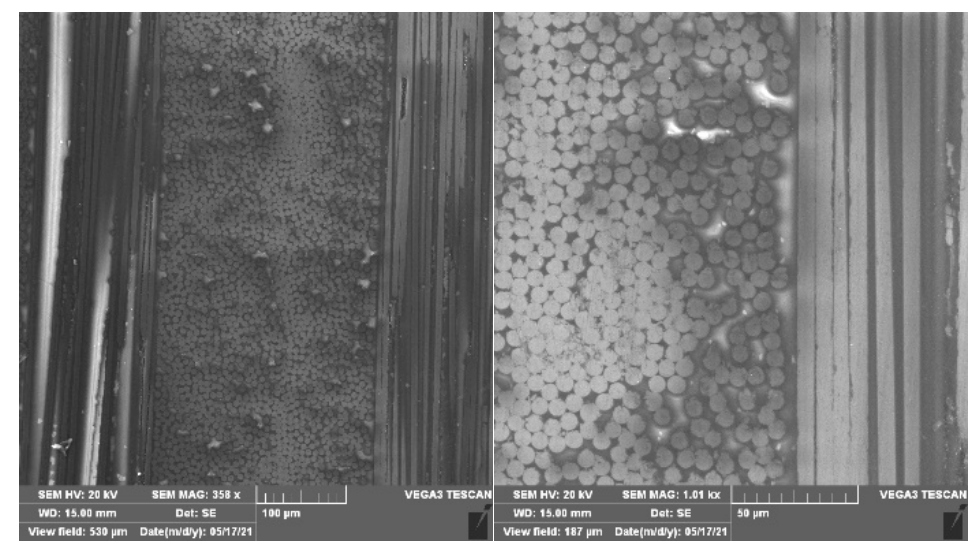

Laminate SL23PL40 PAEK/CF (4.31\% voids)

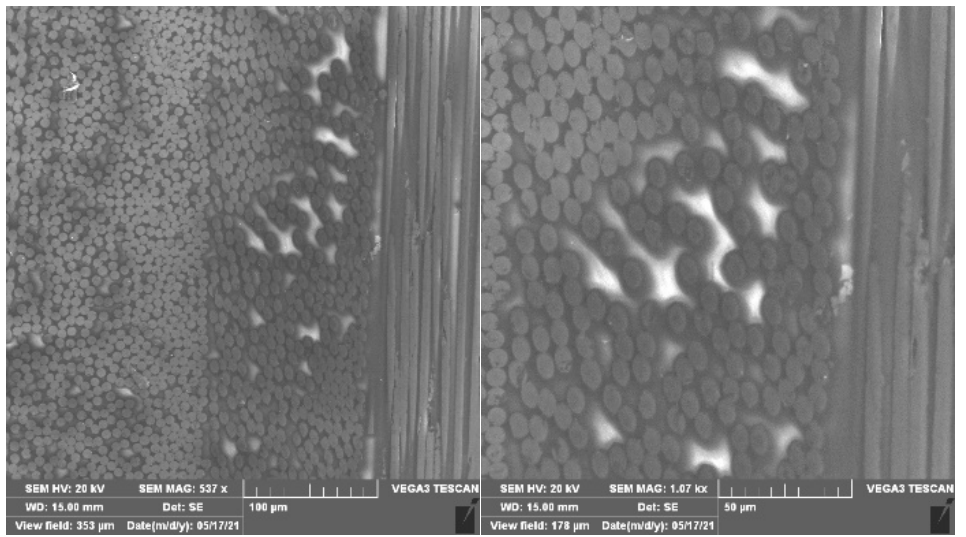

Laminate SL23PL41 PAEK/CF (1.76\% voids)

Figure 10. SEM images of the samples with PAEK resin.

\section{Conclusions}

From the analysis of the influence of the parameters of the tape width (contact line) for various factors explained in this paper, it was concluded that the design of the compaction roller (the thickness of the siliconized layer) and the angle of laying have a great influence. The following conclusions can be drawn from the results:

- The results confirmed that each laying angle of the laminate gives a different contact surface.

- From all four types of angles in this paper, the angle of laying in the direction of the fibers (0) gave the largest surface; thus, giving good intimate contact for good consolidation and adhesion on the stencil, and thus gluing layer by layer.

- For QI laminate with other angles $( \pm 45 ; \pm 30 ; 90)$, we need to increase or decrease the compaction force (according to Figures 6 and 7) to have a similar compact line (surface), as well as for the laying of the fibers in the direction (0) in order to have an even bonding of the layers without gap and overlap.

From the analysis of tested samples based on PEKK and PAEK resin, No. 1-8 could be summarized:

- The minimum lay-up speed and the maximum compact force for both materials have the best results (low porosity less than $2 \%$ ).

- The selected parameters for the samples with PEEK resin have better mechanical characteristics than the PAEK samples. The reason for that may be the greater flow of the PAEK resin, which can be seen from the SEM images. 
Author Contributions: Conceptualization, S.R. and S.S.; methodology, V.S.; software, S.R.; validation, S.R., S.S. and V.S.; formal analysis, S.R.; investigation, S.R., S.S. and V.S.; resources, S.R.; data curation, S.R.; writing—original draft preparation, S.R.; writing—review and editing, S.R.; visualization, S.R.; supervision, S.S. and V.S. project administration, S.R., S.S. and V.S.; funding acquisition S.S. and V.S. All authors have read and agreed to the published version of the manuscript.

Funding: This research received no external funding.

Institutional Review Board Statement: Not applicable; this study did not involve humans or animals.

Informed Consent Statement: Not applicable; this study did not involve humans or animals.

Data Availability Statement: The data presented in this study are available from the corresponding author upon request.

Acknowledgments: The authors would like to acknowledge the support of the research team from the Institute for advanced composites and robotics_-Prilep (North Macedonia), and the engineering team from Mikrosam D.O.O.-Prilep (North Macedonia).

Conflicts of Interest: The authors declare no conflict of interest.

\section{References}

1. Lee, W.I.; Springer, G.S. A model of the manufacturing process of thermoplastic matrix composites. J. Compos. Mater. 1987, 21, 1017-1055. [CrossRef]

2. Yang, F.; Pitchumani, R. A fractal Cantor set based description of interlaminar contact evolution during thermoplastic composites processing. J. Mater. Sci 2001, 36, 4661-4671. [CrossRef]

3. Schaefer, P.M.; Guglhoer, T.; Sause, M.G.; Drechsler, K. Development of intimate contact during processing of carbon fiber reinforced Polyamide-6 tapes. J. Reinf. Plast. Compos. 2017, 36, 593-607. [CrossRef]

4. Mantell, S.C.; Springer, G.S. Manufacturing process models for thermoplastic composites. J. Compos. Mater. 1992, 26, $2348-2377$. [CrossRef]

5. Khan, M.A.; Mitschang, P.; Schledjewski, R. Parametric study on processing parameters and resulting part quality through thermoplastic tape placement process. J. Compos. Mater. 2013, 47, 485-499. [CrossRef]

6. Stokes-Griffin, C.M.; Compston, P. Investigation of sub-melt temperature bonding of carbon-fibre /PEEK in an automated laser tape placement process. Compos. Part A Appl. Sci. Manuf. 2016, 84, 17-25. [CrossRef]

7. Jiang, J.; He, Y.; Ke, Y. Pressure distribution for automated fiber placement and design optimization of compaction rollers. J. Reinf. Plast. Compos. 2019, 38, 860-870. [CrossRef]

8. Stokes-Griffin, C.M.; Compston, P. A combined optical-thermal model for near-in-frared laser heating of thermoplastic composites in an automated tape placement process. Compos. Part A Appl. Sci. Manuf. 2015, 75, 104-115. [CrossRef]

9. Grouve, W.J.B.; Warnet, L.L.; Rietman, B.; Visser, H.A.; Akkerman, R. Optimization of the tape placement process parameters for carbon-PPS composites. Compos. Part A Appl. Sci. Manuf. 2013, 50, 44-53. [CrossRef]

10. Leon, A.; Argerich, C.; Barasinski, A.; Soccard, E.; Chinesta, F. Effects of material and process parameters on in-situ consolidation. Int. J. Mater. Form. 2019, 12, 491-503. [CrossRef]

11. Coulson, M.; Dantras, E.; Olivier, P.; Gleizes, N.; Lacabanne, C. Thermal conductivity and diffusivity of carbon-reinforced polyetherketoneketone composites. J. Appl. Polym. Sci. 2019, 136, 47975. [CrossRef]

12. Grouve, W.J.B.; Warnet, L.L.; Rietman, B.; Akkerman, R. On the weld strength of in situ tape placed reinforcements on weave reinforced structures. Compos. Part A Appl. Sci. Manuf. 2012, 43, 1530-1536. [CrossRef]

13. Barasinski, A.; Leygue, A.; Soccard, E.; Poitou, A. Identification of non uniform thermal contact resistance in automated tape placement process. Int. J. Mater. Form. 2014, 7, 479-486. [CrossRef]

14. Simacek, P.; Advani, S.G.; Gruber, M.B.; Jensen, B. A non-local void filling model to describe its dynamics during processing thermoplastic composites. Compos. Part. A Appl. Sci. Manuf. 2013, 46, 154-165. [CrossRef]

15. Mehdikhani, M.; Gorbatikh, L.; Verpoest, I.; Lomov, S.V. Voids in fiber-reinforced polymer composites: A review on their formation, characteristics, and effects on mechanical performance. J. Compos. Mater. 2019, 53, 1579-1669. [CrossRef]

16. Stokes-Griffin, C.M.; Compston, P. The effect of processing temperature and placement rate on the short beam strength of carbon fibre-PEEK manufactured using a laser tape placement process. Compos. Part A Appl. Sci. Manuf. 2015, 78, 274-283. [CrossRef]

17. Weiler, T.; Emonts, M.; Wollenburg, L.; Janssen, H. Transient thermal analysis of laser-assisted thermoplastic tape placement at high process speeds by use of analytical solutions. J. Thermoplast. Compos. Mater. 2018, 31, 311-338. [CrossRef]

18. Butler, C.A.; McCullough, R.L. An analysis of mechanisms governing fusion bonding of thermoplastic composites. J. Thermoplast. Compos. Mater. 1998, 11, 339-363. [CrossRef]

19. Levy, A.; Heider, D.; Tierney, J.; Gillespie, J.W. Inter-layer thermal contact resistance evolution with the degree of intimate contact in the processing of thermoplastic composite laminates. J. Compos. Mater. 2014, 48, 491-503. [CrossRef] 
20. Tierney, J.; Gillespie, J.W. Modeling of in situ strength development for the thermoplastic composite tow placement process. J. Compos. Mater. 2006, 40, 1487-1506. [CrossRef]

21. Zarandi, M.A.F.; Arroyo, S.; Pillai, K.M. Longitudinal and transverse flows in fiber tows: Evaluation of theoretical permeability models through numerical predictions and experimental measurements. Compos. Part A Appl. Sci. Manuf. 2019, $119,73-87$. [CrossRef]

22. Kok, T. On the Consolidation Quality in Laser Assisted Fiber Placement: The Role of the Heating Phase. Ph.D. Thesis, University of Twente, Enschede, The Netherlands, 2018. [CrossRef]

23. Comer, A.J.; Ray, D.; Obande, W.O.; Jones, D.; Lyons, J.; Rosca, I.; Higgins, R.M.O.; McCarthy, M.A. Mechanical characterisation of carbon fibre-PEEK manufactured by laser-assisted automated-tape- placement and autoclave. Compos. Part A Appl. Sci. Manuf. 2015, 69, 10-20. [CrossRef]

24. Lichtinger, R.; Lacalle, J.; Hinterh€olzl, R.; Beier, U.; Drechsler, K. Simulation and experimental validation of gaps and bridging in the automated fiber placement process. Sci. Eng. Compos. Mater. 2015, 22, 131-148. [CrossRef]

25. Lukaszewicz, D.-J.; Potter, K. Through-thickness compression response of uncured prepreg during manufacture by automated layup. Proc. Inst. Mech. Eng. Part B J. Eng. Manuf. 2012, 226, 193-202. [CrossRef]

26. Cheng, J.; Zhao, D.; Liu, K.; Wang, Y.; Chen, H. Modeling and impact analysis on contact characteristic of the compaction roller for composite automated placement. J. Reinf. Plast. Compos. 2018, 37, 1418-1432. [CrossRef]

27. Samak, S.; Risteska, S.; Dukovski, V.; Trajkoski, S. Some experimental investigation of products from thermoplastic composite materials manufactured with robot and LAFP. Int. J. Eng. Res. Technol. 2020, 9, 9. Available online: https://www.ijert.org/someexperimental-investigation-of-products-from-thermoplastic-composite-materials-manufactured-with-robot-and-lafp (accessed on 15 September 2021).

28. Saffar, F.; Sonnenfeld, C.; Beauchêne1, P.; Park, C.H. In-situ Monitoring of the Out-Of-Autoclave Consolidation of Carbon/PolyEther-Ketone-Ketone Prepreg Laminate. Front. Mater. 2020, 7, 195. [CrossRef]

29. Thor, M.; Sause, M.G.R.; Hinterhölzl, R.M. Mechanisms of Origin and Classification of Out-of-Plane Fiber Waviness in Composite Materials-A Review. J. Compos. Sci. 2020, 4, 130. [CrossRef]

30. Celik, O.; Peeters, D.; Dransfeld, C.; Teuwen, J. Intimate contact development during laser assisted fiber placement: Microstructure and effect of process parameters. Compos. Part A: Appl. Sci. Manuf. 2020, 134, 105888. [CrossRef]

31. Baho, O.; Ausias, G.; Grohens, Y.; Férec, J. Simulation of laser heating distribution for a thermoplastic composite: Effects of AFP head parameters. Int. J. Adv. Manuf. Technol. 2020, 110, 2105-2117. [CrossRef]

32. Srebrenkoska, S.; Dukovski, V.; Risteska, S. Influence of the process parameters on laser-Assisted automated tape placement process. Int. J. Eng. Res. Technol. 2020, 9, 11. Available online: https://www.ijert.org/influence-of-the-process-parameters-onlaser-assisted-automated-tape-placement-process (accessed on 15 September 2021).

33. Stokes-Griffin, C.M.; Compston, P. An inverse model for optimisation of laser heat flux distributions in an automated laser tape placement process for carbon-fibre/PEEK. Compos. Part. A Appl. Sci. Manuf. 2016, 88, 190-197. [CrossRef]

34. Kim, Y.H.; Wool, R.P. A theory of healing at a polymer-polymer interface. Macromolecules 1983, 16, 1115-1120. [CrossRef] 